\title{
INTERGENERATIONAL MOBILITY OF INCOME AND SCHOOLING: CHILE 1996-2006
}

MOVILIDAD INTERGENERACIONAL DEL INGRESO Y LA EDUCACION: CHILE 1996-2006

\section{PABLO CELHAY}

ILADES-Universidad Alberto Hurtado

\section{CLAUDIA SANHUEZA}

ILADES-Universidad Alberto Hurtado

\section{JOSE R. ZUBIZARRETA}

University of Pennsylvania

\begin{abstract}
In this paper we analyze intergenerational income and schooling mobility during the 1996-2006 decade in Chile. Using the countries most extended household panel survey, we overcome some of the limitations of the previous Chilean studies by using observed income data for both parents and children, as opposed to observed income data only for children and income data that is generated for parents from the information given by their children retrospectively. Following the recent literature, we control our estimates for time-series variation (Lee and Solon, 2009). Our results show high intergenerational income elasticities in comparison to other developing countries, and these values are higher for sons than for daughters. The same results hold for educational mobility. Trends analysis show that the transmission of economic status have remained constant during the last years in Chile, while educational mobility has increased.
\end{abstract}

Keywords: Social mobility, panel data, educational mobility.

JEL Classification: D69. 


\section{Resumen}

En este trabajo se estudia la movilidad intergeneracional del ingreso y la educación durante la década de 1996 al 2006 para Chile. Utilizando los datos de panel más amplios del país se solucionan algunas limitaciones de estudios anteriores pues se utilizan datos observados tanto para padres como hijos(as) en lugar de utilizar como ingreso de los padres una estimación de sus ingresos utilizando información retrospectiva entregada por sus hijos(as) en encuestas de corte transversal. Siguiendo la literatura reciente, controlamos nuestros estimadores por variaciones en el tiempo (Lee y Solon, 2009). Los resultados muestran altas elasticidades de ingreso intergeneracional en comparación con otros países en desarrollo, valores que son aún mayores para hijos en comparación con la muestra de hijas. Los mismos resultados se encuentran para movilidad educacional. Por otro lado, un análisis de tendencias muestra que la transmisión intergeneracional de ingresos se ha mantenido constante en los últimos años, mientras que la movilidad educacional aumenta.

Palabras Clave: Movilidad social, datos de panel, movilidad educacional

Clasificación JEL: D69.

\section{INTRODUCTION}

The extent to which economic status is transmitted from one generation to the next has scarcely been studied in Chile mainly due to the lack of longitudinal data. Addressing this question is important because it can shed light on the underlying mechanics of Chilean income inequality, and help to assess the degree to which the norm of equal opportunity is met in the society.

In this paper we estimate the intergenerational income elasticity and schooling correlations in Chile using for the first time observed data for both parents and children. Following Lee and Solon (2009), we generate estimates of the recent time-series variation in intergenerational mobility.

In the context of Latin America, Chile has been pointed out as an example for its stable macroeconomic policies and focused social programs. These have provided sustained economic growth and double of the country's income per capita during the last decade. Also, they have helped to reduce poverty from more than 40 percent at the end of the 1980s to 15 percent in 2009 (CASEN surveys). In spite of this growth, income distribution has persisted, and Chile also has been pointed out as being one of the most inequitable countries of Latin America. In fact, Latin Americas countries have some of the most unequal income distributions of the world according to the WDR 2006, and within this context of high inequality Chile stands out, close to Brazil, averaging a Gini of 0.57 over the 1987-2006 period (CASEN surveys). Several studies 
have analyzed income inequality in Chile (for instance, Contreras, 1999; López and Miller, 2008; Meller, 2000; Sapelli, 2005; Solimano and Torche, 2008), but few have focused on the dynamics that configure this distribution.

While poverty and inequality measures help to evaluate a country's welfare performance in several periods, mobility indices quantify changes in the life conditions of households more rigorously across time. However, this type of analysis relies on repeated measurements of the same individuals over time or longitudinal data, which only recently became available in Chile. In this study we draw upon the data of the Panel CASEN survey, which with three waves in 1996, 2001 and 2006 cover a ten year period, being one of the longest household panel survey conducted in less developed countries (Fields et al., 2006; Jenkins and Siedler, 2007b; Lawson et al., 2003).

Previous analyses of the transmission of economic status in Chile have used crosssectional data to estimate the intergenerational income elasticity, however they did not observe longitudinal data. For instance, Núñez and Risco (2004) and Torche (2005) use a separate data set on the parent's generation to estimate a first-stage regression of parent's log incomes on his education and occupation. After that, in a second stage, they estimate the regression of the children's log incomes on a prediction of his or her parent's log incomes based on the first-stage regression. As Solon (2002) highlights, this two-stage procedure that uses education and occupation to predict parent's incomes is likely to lead to an upward bias. As he explains, the problem is that these first-stage parent's variables are not only associated with the children's incomes, but also might be positive predictors of the children's income even after conditioning on the parent's incomes. In the second-stage regression, when the parent's education and occupation is used only to predict the parent's incomes, it is not used as a separate explanatory variable in its own right, the resulting omitted-variables bias may lead to overestimation of the intergenerational earnings elasticity. ${ }^{1}$ In this way, their estimate may be biased upward by their prediction of parent's income on the basis of their education and occupation. As we already mentioned, in this paper we overcome this problem by relying on observed data for both parents and children. We make this more precise in the next Section, where we explain the econometric model. Afterwards, in Section 3, we describe the Panel CASEN and our sample of parents and children. In Section 4 we report our results and in Section 5 we make our conclusions.

\section{ECONOMETRIC SPECIFICATION}

The basic relationship that we analyze in this paper is that between parents' economic status $y_{p}$ and a child's economic status in adulthood $y_{c}{ }^{2}$ In a similar way to Mayer and Lopoo (2004) we use household income rather than father's earnings as our measure of parents' economic status because household income is a better proxy for the investments that can be made in the child. Like most of the economic

Solon (1992) also provides a mathematical analysis of this problem.

The same analysis is done by changing economic status by years of schooling for parents and children to estimate intergenerational schooling correlations. 
literature, we use a log-linear regression model, which assumes that the log of the child's income can be expressed as a linear function of his or her parents log income, according to

$$
\log \left(y_{p}\right)=\beta_{0}+\beta_{1} \log \left(y_{c}\right)+\varepsilon
$$

In this equation, $\beta_{0}$ is the intercept term that denotes the change in status common to all the children, $\beta_{1}$ is our parameter of interest that represents the elasticity of children's permanent income with respect to parents' permanent income, and $\varepsilon$ is a random error term. Like this, if the variances of the permanent incomes of the parents and children are equal, two extreme cases can be considered: a value of $\beta_{1}=0$, which indicates that there is complete mobility, in the sense that the child's economic position is completely independent of the position of his or her parents; and $\beta_{0}=0$, which indicates complete immobility, in that the child's position is totally determined by the position of his or her parents.

Following Solon (1992), Solon (2002) and Mayer and Lopoo (2008), the economic theory underlying this equation is a human capital model in which a child's economic status is a function of both child's endowments and parents' monetary investments in the child's human capital. Endowments include personal attributes like ability and temperament, which are determined by genes as well as by parenting styles. ${ }^{3}$ On the other hand, monetary investments correspond to goods and services that benefit the development of the child and result in better outcomes, which in the end determine the child's economic status in adulthood. ${ }^{4}$ Examples of these goods and services are healthy food, stimulating toys and better schooling. In this model, if some parents can invest more in their children than others, their children will have on average better outcomes than similarly endowed children.

As Mayer and Lopoo (2008) also note, if rich parents can buy better goods and services for their children, and rich and poor children take equal advantage from these goods and services, the fact that rich children get better schooling violates norms of equal opportunity. In this regards, our estimates of the intergenerational income elasticity could provide insight about the extent to which equal opportunity is met in Chile.

In an ideal setting, we would estimate the intergenerational elasticity with parental income averaged over all the years after a child was born, as a measure of permanent income in order to reduce response error and transitory fluctuations in incomes (Solon (2002)). Unfortunately, there is no longitudinal data set suitable for this type of analysis that contains lifetime income data on both generations. For this reason most studies rely on short-run income measures to proxy for long-run economic status, and they control for the life-cycle stage of both children and parents at the times their incomes

3 For further discussion on models of intergenerational transmission of economic status and the importance of mobility see Galiani (2010).

4 For a study along these lines, see Zubizarreta (2009). With data from the Panel CASEN he estimates the impact of experiencing poverty or low household incomes during childhood on educational outcomes during early adulthood in Chile. 
are observed as in Lee and Solon (2009). Along these lines, we extend the analysis of equation 1 by letting

$$
\log \left(y_{p}\right)=\beta_{0}+\beta_{1} \log \left(y_{c}\right)+\beta_{2} a_{c}+\beta_{3} a_{c}^{2}+\beta_{4} a_{p}+\beta_{5} a_{p}^{2}+\beta_{6} t+\varepsilon
$$

where $a_{c}$ and $a_{p}$ stand for the children and parents age respectively, and $t$ is time dummy that controls for the parents' cohort. Another restriction imposed by our data is that incomes are measured monthly for each wave.

The literature documents the "noisiness" of short-run income measures as proxies for long-run economic status which causes an attenuation inconsistency in the estimation of the intergenerational income elasticity, or more simply, an underestimation of the intergenerational income correlation (Solon, 1992). In view of this, we present two sets of estimates: one with parents' household incomes measured in the first wave only, and another with parents' household incomes measured across the first two waves. In this sense, our results from the first set will provide conservative estimates of the degree of intergenerational transmission of income. ${ }^{5}$ On the other hand, Bjorklud and Jantti (1997) propose using instrumental variables in two samples (2SIV) to estimate intergenerational mobility. In this case, the parental income is instrumented by the parental level of schooling. However, this latter methodology overestimates the real parameter and therefore estimates a lower level of mobility. For our case, we did not use 2SIV but rather take a time series approach to account noisy short run fluctuations.

We also distinguish the estimations between daughters and sons. Lee and Solon (2009) found that daughters have better outcomes in terms of intergenerational mobility than sons. This may be due to the marriage market in which it is more possible for a woman to married a more educated men than the other way around.

\section{DATA AND DESCRIPTIVE STATISTICS}

The Panel CASEN Survey is based on the CASEN cross section survey taken in 1996, the most relevant socio economic survey in Chile with national and regional representation. The first wave of the panel is a sub sample of the CASEN survey 1996 which was re interviewed in years 2001 and 2006. Follow up interviews were taken in the Third, Seventh, Eighth and Metropolitan Regions which represented about $60 \%$ of the Chilean population.

As Francesconi and Nicoletti (2006) note, there maybe selection problems in intergenerational mobility studies driven by the fact that the time series component of the data set is not long enough. Indeed, when working with longitudinal data that extends for less than 20 years, for example, the choice of the generation of the children is constrained by the trade-off between younger and older children. While the younger children are likely to conform a random sample of the population of children living with their parents, their observed economic status is likely to be a poor proxy of their long-run economic status. On the other hand, older children will have better measures of their long-run economic status, but this sample may over represent children who will not leave their parents' home until much later in their lives and reach a different economic status later in life. This is an issue that will be addressed in future work. 
The analysis in this article combines different birth cohorts of children, one of children born between 1961 and 1981, and one of children born in 1966 and 1986. The first cohort groups sons and daughters in waves 1996 and 2001 of the panel data set that became household heads in the third wave of the panel, year 2006. The second cohort groups sons and daughters in waves 1996 that became household heads or spouse in 2001 and continued in either of these household categories in the third wave of the panel, in 2006. Therefore, we observe household total income for both groups when they were sons or daughters and when they became household heads or spouse.

The original data contains 9,436 children in total in 1996, from which 3,141 belong to the cohorts defined above. Along with this cohort restriction, the estimation of intergenerational mobility restricts the sample to those children in the cohorts defined for whom we observe household income data when they are children, and those children that became household heads in succeeding waves. Finally, the estimations below use a sample size of 1,025 observations.

When pairs of family income in $t=1$ and $t=2$ are constructed, the observations that are children in years 1996 and 2001 or become household heads or spouse in year 2006 turn into two different observations: i) being children in year 1996 and household head or spouse in year 2006, and ii) children in year 2001 and household head or spouse in 2006. Thus from the 1,025 observations above, the final number of observation increases approximately to 1,700 .

\section{TABLE 1}

\section{INTERGENERATIONAL INCOME ELASTICITIES IN OTHER COUNTRIES}

\begin{tabular}{|l|c|c|c|l|}
\hline \multicolumn{1}{|c|}{ Country } & OLS & IV & Cohort & \multicolumn{1}{|c|}{ Source } \\
\hline Germany & $0.11-0.34$ & & & Couch and Dunn (1997), Wiegand (1997) \\
Brazil & $0.53-0.54$ & $0.54-0.74$ & & Dunn (2003) \\
Canada & $0.12-0.19$ & & & Corak y Heisz (1995) \\
Chile & 0.54 & 0.58 & & Núñez y Risco (2004) \\
Spain & 0.24 & 0.44 & & Sánchez (2004) \\
USA & $0.29-0.49$ & $0.44-0.53$ & & Solon (1992) \\
USA & $0.2-0.6$ & & yes & Lee and Solon (2006) \\
Finland & 0.13 & & & Osterbacka (2001) \\
France & 0.41 & 0.44 & & Lefrane y Trannoy (2004) \\
UK & 0.43 & 0.57 & & Dearden, Machin, and Reed (1997) \\
Italy & 0.36 & & & Checchi (1997) \\
Malaysia & 0.26 & & Lilland and Kilburn (1995) \\
South Africa & 0.44 & & Solon (2002), Solon (2006) \\
Sweden & 0.13 & & & Osterberg (2000) \\
\hline
\end{tabular}

Source: Núñez y Risco (2004), Solon (2006).

Given this sample structure we can observe sons' and daughters' household total income in ages that vary between 9 to 35 years old, and their household total income 
when they become household head or spouse in ages between 20 to 45 years old. In our analysis, we follow Lee and Solon (2009) to consider the effects of observing children income over a range of ages, which may cause a life cycle bias.

Table 2 shows a descriptive statistical analysis of the data with the variables included in the multivariate analysis. In the period we observe children as sons and daughters $(t=1)$. The mean age is 20.85 years old (within a range of 9 to 35 years for the cohorts chosen). Children's household mean total income is of $\$ 338,329$ Chilean pesos (660 USD). Household's head age in $t=1$ is around 50 years old and have on average approximately 7-8 years of schooling. And $80 \%$ of household head, in the same period are male. When we observe children as household heads or spouse, their mean age is 28 years old (within a range of 20 to 45 years); they have 12.45 years of schooling, approximately $44 \%$ of them are male, and their household income is on average $\$ 414,329$ Chilean pesos (813 USD).

\section{TABLE 2}

\section{DESCRIPTIVE STATISTICS OF THE SAMPLE}

\begin{tabular}{|l|c|c|c|}
\hline \multicolumn{1}{|c|}{ Variables } & Mean & Std. Err. & Obs. \\
\hline Children age in $t=1$ & 20.85 & 0.254 & 1,695 \\
Children household total income in $t=1$ & $338,329.6$ & $25,428.3$ & 1,720 \\
Children log household total income in $t=1$ & 12.359 & 0.056 & 1,708 \\
Household head age in $t=1$ & 49.972 & 0.630 & 1,648 \\
Household head age square in $t=1$ & $2,597.3$ & 68.9 & 1,648 \\
Household schooling in $t=1$ & 7.583 & 0.363 & 1,553 \\
Household head sex in $t=1$, dummy $=1$ if male & 0.798 & 0.022 & 1,717 \\
\hline Children age in $t=2$ & 27.971 & 0.266 & 1,705 \\
Children age square in $t=2$ & 808.6 & 15.2 & 1,705 \\
Children schooling in $t=2$ & 12.5 & 0.248 & 1,645 \\
Children gender in $t=2$, dummy $=1$ if male & 0.441 & 0.027 & 1,716 \\
Children household total income in $t=2$ & $414,329.6$ & $44,136.2$ & 1,720 \\
Children log household total income in $t=2$ & 12.553 & 0.077 & 1,700 \\
\hline
\end{tabular}

Note: All statistics are calculated using longitudinal weights of the sample.

All incomes expressed here are in real terms, using 1996 as the base year. Figure 1 shows the density distributions for the log income of the child in $t=2$ and of the household in $t=1$, showing a lightly greater income in all points of the distribution for $t=1$, mainly due to a difference in life cycle between the two periods that will be accounted for in the multivariate analysis. All estimates in this article are calculated using the weights of the panel data set corrected for attrition as explained by Paredes et al. (2006). 


\section{FIGURE 1}

\section{CHILDHOOD/ADULTHOOD INCOME DENSITY DISTRIBUTIONS}

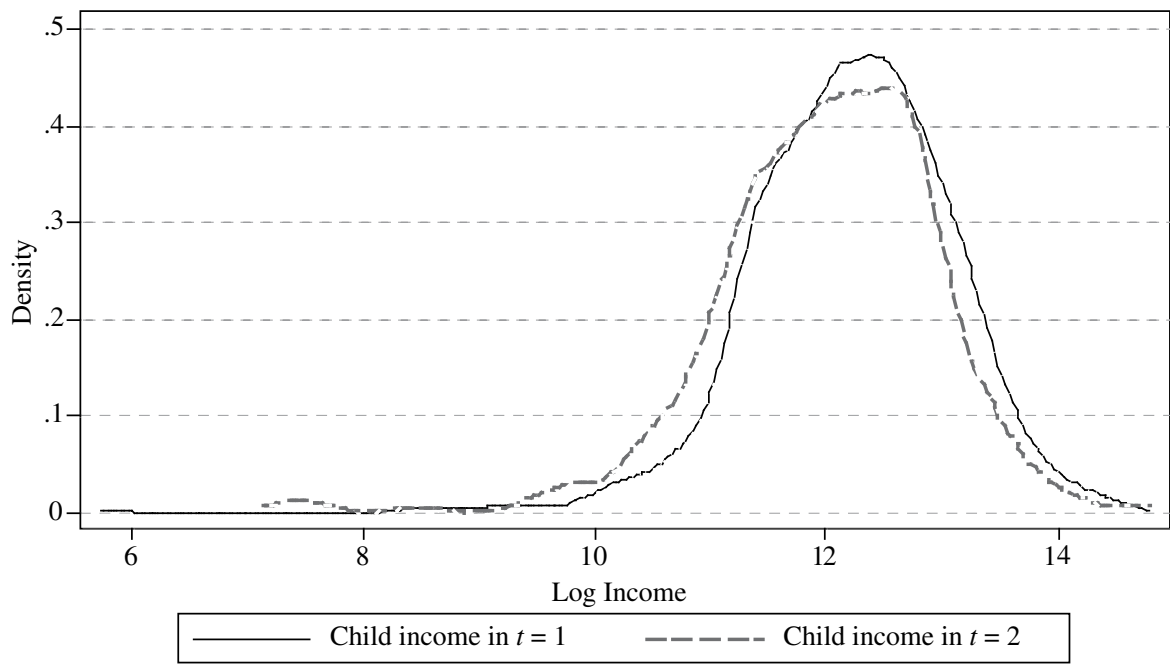

\section{A DESCRIPTIVE APPROACH TO MOBILITY}

Income mobility can be studied through different analysis. One of them is the analysis of positional movements using mobility matrices to study mobility between two different categories of the same dimensions (time, generation, geographical, etc.).

Table 3 shows a mobility matrix for quantiles of income. The rows show the quantile of household total income in $t=1$, that is when the child has not yet become a household head. In the columns, the table shows the quantiles of household total income when the child becomes a household head. For instance, the table shows that $43 \%$ of children whose childhood household was in the first quantile of income, remained in this position when they became household heads. ${ }^{6}$ Furthermore, $6.5 \%$ of these children jumped to the highest quantile of income in adulthood. The table also shows that mobility is higher in the middle quantiles of income. ${ }^{7}$ In the highest quantile of income, the table shows that while $56.8 \%$ of children whose childhood household was in the highest quantile of income remained in this position when they became household heads, and less than $20 \%$ of them fell two or more positions. It seems that mobility of income between generations is higher in the lower part of the

\footnotetext{
6 Note however that because of the construction of these matrices, quantiles in the extremes are wider, and quantiles in the middle are narrower.

7 Ibid.
} 
income distribution than in the top of the distribution. This is consistent with Torche (2005) that shows Chile as a country with higher mobility in lower levels of the income distribution.

Various measures can be obtained from transition or mobility matrices as shown bellow in Table 3. The first of them shows the percentage of sample members in the diagonal of the mobility matrix. From the matrix we obtain that $38 \%$ of children remained in the same position when they became household heads. The next two measures are the Shorrocks MET - Prais Index (Shorrocks 1978) and the Average Jump measure. The latter measures the average jump between deciles of each observation in our sample, while the former is an index that ranges between 0 and 1 , where 0 is perfect mobility of the observations in the sample. The Shorrock's index shows a value of 0.87 . The average jump index shows that when children become household heads move, on average, 1.18 quantiles, upwards or downwards, from their childhood household income decile.

\section{TABLE 3}

INCOME MOBILITY MATRIX AND MOBILITY MEASURES

\begin{tabular}{|c|c|c|c|c|c|c|}
\hline \multirow{7}{*}{ 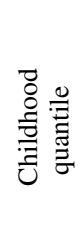 } & & \multicolumn{5}{|c|}{ Adulthood quantile } \\
\hline & & I & II & III & IV & $\mathrm{V}$ \\
\hline & I & $43.0 \%$ & $18.8 \%$ & $17.2 \%$ & $14.6 \%$ & $6.5 \%$ \\
\hline & II & $25.7 \%$ & $22.3 \%$ & $16.2 \%$ & $18.7 \%$ & $17.1 \%$ \\
\hline & III & $11.4 \%$ & $21.0 \%$ & $19.3 \%$ & $27.8 \%$ & $20.5 \%$ \\
\hline & IV & $10.7 \%$ & $11.3 \%$ & $15.7 \%$ & $26.0 \%$ & $36.3 \%$ \\
\hline & $\mathrm{V}$ & $3.8 \%$ & $6.7 \%$ & $9.0 \%$ & $23.8 \%$ & $56.8 \%$ \\
\hline \multirow{3}{*}{\multicolumn{4}{|c|}{$\begin{array}{l}\text { Percentage on diagonal } \\
\text { Shorrocks' MET-the Prais index } \\
\text { Average Jump }\end{array}$}} & $38 \%$ & & \\
\hline & & & & 0.87 & & \\
\hline & & & & 1.188 & & \\
\hline
\end{tabular}

The same analysis has been done to study schooling mobility in the sample. Results are shown in Table 4. Years of schooling were grouped into 5 categories: less than 4 years of schooling, 4 to 8 years of schooling, 8 to 12 years of schooling, 13 to 15 years of schooling, and 16 or more years of schooling. The results show that mobility is higher for lower levels of schooling. This may be a result from promoting schooling by the Chilean government in the last decades. Most of the sample from lower levels of schooling (first three categories) jumped to higher school levels (9 to 12 years of schooling). In the highest level of schooling, however, the story is different and there is more rigidity. As much as $82.4 \%$ of children whose household head in childhood had 16 or more years of schooling achieved similar levels of schooling. The measures obtained from the schooling mobility matrix show higher mobility for education levels than income quantiles. The percentage of children that stayed in the same level as their household heads during childhood is $21 \%$. Furthermore, schooling mobility shows a lower Shorrocks' index but a lower average jump. The results of schooling mobility 
analysis may be evidence that schooling policies are being effective in primary and secondary school levels however not in tertiary levels of schooling. Even more, the lower level of mobility in higher level of schooling can also affect income mobility since it is well known that in Chile returns to schooling are concave so the higher the level of schooling the greater is the return to each year of schooling.

TABLE 4

SCHOOLING MOBILITY MATRIX AND MOBILITY MEASURES

\begin{tabular}{|l|c|r|r|r|r|}
\hline & \multicolumn{5}{|c|}{ Adulthood schooling } \\
\cline { 2 - 6 } & less than 4 & 4 to 8 & 9 to 12 & 13 to 15 & 16 or more \\
\hline Household head & $1.2 \%$ & $39.1 \%$ & $45.4 \%$ & $11.4 \%$ & $2.9 \%$ \\
4 to 8 & $0.2 \%$ & $8.9 \%$ & $61.7 \%$ & $21.2 \%$ & $8.0 \%$ \\
9 to 12 & $0.3 \%$ & $1.1 \%$ & $38.2 \%$ & $25.9 \%$ & $34.5 \%$ \\
13 to 15 & $0.0 \%$ & $0.0 \%$ & $7.2 \%$ & $91.0 \%$ & $1.8 \%$ \\
16 or more & $0.0 \%$ & $2.0 \%$ & $3.3 \%$ & $12.3 \%$ & $82.4 \%$ \\
\hline Percentage on diagonal & & $21 \%$ & \\
Shorrocks' MET-the Prais index & 0.716 & \\
Average Jump horrocks (1978) relative mobility measures & 0.869 & \\
\hline
\end{tabular}

\section{REGRESSION RESULTS}

Following the descriptive analysis and transition matrices for income mobility, we now present results from the empirical models presented in Section 2. We estimate intergenerational income elasticities and schooling correlations controlling for the age of the child when his or her income as an adult is observed, this same age squared, age of the father when childhood household income is observed, this age squared and a dummy for year to control for time specific effects. We also analyze income elasticities and schooling correlations with cohorts in two different models: a) one where the interaction is done with aggregated cohorts of 10 years, and b) another one where the interaction is done with annual cohorts that allow to study mobility in a year by year basis. We present results for all samples, only sons and only daughters. We recall that the higher the parameter the lower the intergenerational mobility. As we said before, in the international literature this parameter is in generally low in Scandinavian countries, and is higher in the US and much higher in Brazil, for example.

Table 5 shows the childhood/adult elasticities for income estimated from equations in Section 2. The first row of Table 5 shows an intergenerational income elasticity of $50.5 \%$ for the full sample, i.e. an increase in $1 \%$ of the income of the children household result in an increase of $0.5 \%$ of the income of the child in adulthood. This is a similar number to the one found by Núñez and Risco (2004) for Chile. Mobility is higher for the sub sample of daughters. While the child/adult elasticity of income is $59 \%$ for men, women have an intergenerational income elasticity of $42.6 \%$. This difference of 18 percentage points suggests that women tend to have better outcomes 
in terms of income mobility than men once they leave their son/daughter status in the household. The three parameters shown are higher than those of Lee and Solon (2009) for the US. ${ }^{8}$

\section{TABLE 5}

OLS REGRESSIONS FOR INCOME MOBILITY: ALL SAMPLE, SONS, AND DAUGHTERS ESTIMATES

\begin{tabular}{|l|c|c|c|}
\hline \multicolumn{1}{|c|}{ Variables } & All Sample & Sons & Daughters \\
\hline Children log household total income in $t=1$ & $0.505^{* * *}$ & $0.590^{* * *}$ & $0.426^{* * *}$ \\
& $(0.048)$ & $(0.066)$ & $(0.051)$ \\
Children age in $t=2$ & $0.178^{* * *}$ & $0.208^{* *}$ & $0.191^{* *}$ \\
& $(0.064)$ & $(0.105)$ & $(0.084)$ \\
Children age square in $t=2$ & $-0.003^{* * *}$ & $-0.003^{* *}$ & $-0.003^{* *}$ \\
& $(0.001)$ & $(0.001)$ & $(0.001)$ \\
Household head age in $t=1$ & -0.019 & $-0.082^{*}$ & 0.051 \\
& $(0.027)$ & $(0.046)$ & $(0.045)$ \\
Household head age square in $t=1$ & 0.000 & $0.001^{*}$ & -0.000 \\
& $(0.000)$ & $(0.000)$ & $(0.000)$ \\
Year 2001 (= 1 if $t=2$ is 2001, $=0$ if 2006) & $-0.179^{* *}$ & -0.118 & $-0.209^{*}$ \\
& $(0.077)$ & $(0.078)$ & $(0.106)$ \\
Constant & $4.210^{* * *}$ & $4.223^{* * *}$ & $3.266^{* *}$ \\
& $(1.146)$ & $(1.506)$ & $(1.636)$ \\
\hline Observations & 1,604 & 700 & 900 \\
R-squared & 0.304 & 0.363 & 0.278 \\
\hline
\end{tabular}

Standard errors in parentheses.

$* * * \mathrm{p}<0.01, * * \mathrm{p}<0.05, * \mathrm{p}<0.1$.

To study time variant effects of income mobility, the model in Table 6 estimates the same regressions interacting the log of income with a dummy for aggregated cohorts in the data. Three cohorts where constructed, one of children born between 1960-1970, one of children born between 1971-1979, and one of children born between 1980-1989. The interactions show no significant effects suggesting that mobility has experienced no changes during the last decades. This result is in opposition to the results in Sapelli (2005) who found that mobility and inequality for Chile is higher for younger cohorts. However, the data used in that paper is not panel data but a panel of cohort meaning that variation within cohort is not considered as it is in this article.

In Table 7 we analyze the income elasticities with a dummy variable for each cohort in the sample. The cohorts included in this regression are 1966-1986 due to low sample sizes in other cohorts. Figure 2 shows the variation in time of the income elasticity coefficients. Like Lee and Solon (2009) these results control for life cycle

8 Lee and Solon (2009) find parameters of 30\%. However the cohort analysis showed a wide range of results, up to $60 \%$ for income elasticities. 


\section{TABLE 6}

OLS REGRESSIONS FOR INCOME MOBILITY: ALL SAMPLE, SONS, AND DAUGHTERS ESTIMATES. DIFFERENCES BY BIRTH COHORTS

\begin{tabular}{|l|c|c|c|}
\hline \multicolumn{1}{|c|}{ Variables } & All Sample & Sons & Daughters \\
\hline Children log household total income in $t=1$ & $0.488^{* * *}$ & $0.552^{* * *}$ & $0.431^{* * *}$ \\
Children age in $t=2$ & $(0.047)$ & $(0.066)$ & $(0.052)$ \\
& $0.175^{* * *}$ & 0.181 & $0.241^{* * *}$ \\
Children age square in $t=2$ & $(0.064)$ & $(0.116)$ & $(0.085)$ \\
& $-0.003^{* *}$ & -0.002 & $-0.004^{* * *}$ \\
Household head age in $t=1$ & $(0.001)$ & $(0.002)$ & $(0.002)$ \\
& -0.019 & $-0.083^{*}$ & 0.049 \\
Household head age square in $t=1$ & $(0.029)$ & $(0.046)$ & $(0.047)$ \\
& 0.000 & $0.001 * *$ & -0.000 \\
Year 2001 (= 1 if $t=2$ is 2001, 0 if 2006) & $(0.000)$ & $(0.000)$ & $(0.000)$ \\
& -0.126 & -0.032 & -0.190 \\
Household income in $t=1 *$ Cohort (1970-1979) & $(0.125)$ & $(0.157)$ & $(0.125)$ \\
& 0.010 & 0.020 & -0.009 \\
Household income in $t=1 *$ Cohort (1980-1989) & $(0.020)$ & $(0.027)$ & $(0.016)$ \\
Constant & 0.017 & 0.027 & -0.004 \\
& $4.161 * * *$ & $(0.038)$ & $(0.022)$ \\
Observations & $(1.174)$ & $(1.606 * * *$ & 2.615 \\
R-squared & 1,581 & 688 & $(1.698)$ \\
\hline
\end{tabular}

Standard errors in parentheses.

$* * * \mathrm{p}<0.01, * * \mathrm{p}<0.05, * \mathrm{p}<0.1$.

\section{TABLE 7}

\section{OLS REGRESSIONS FOR INCOME MOBILITY. USING LONG TERM INCOME IN $t=1$}

\begin{tabular}{|l|c|}
\hline Variables & All Sample \\
\hline Household longterm income of child $\mathrm{i}$ in $t=1$ & $0.638^{* * *}$ \\
Child age in $t=2$ & $0.084)$ \\
Child age in $t=2$ squared & 0.115 \\
& $(0.135)$ \\
Household head age in $t=1$ & -0.002 \\
& $(0.002)$ \\
Household head age in $t=1$ squared & 0.046 \\
& $(0.045)$ \\
Constant & -0.000 \\
& $(0.000)$ \\
\hline Observations & 1.955 \\
R-squared & $(2.041)$ \\
\hline
\end{tabular}

Standard errors in parentheses.

$* * * \mathrm{p}<0.01, * * \mathrm{p}<0.05, * \mathrm{p}<0.1$. 
FIGURE 2

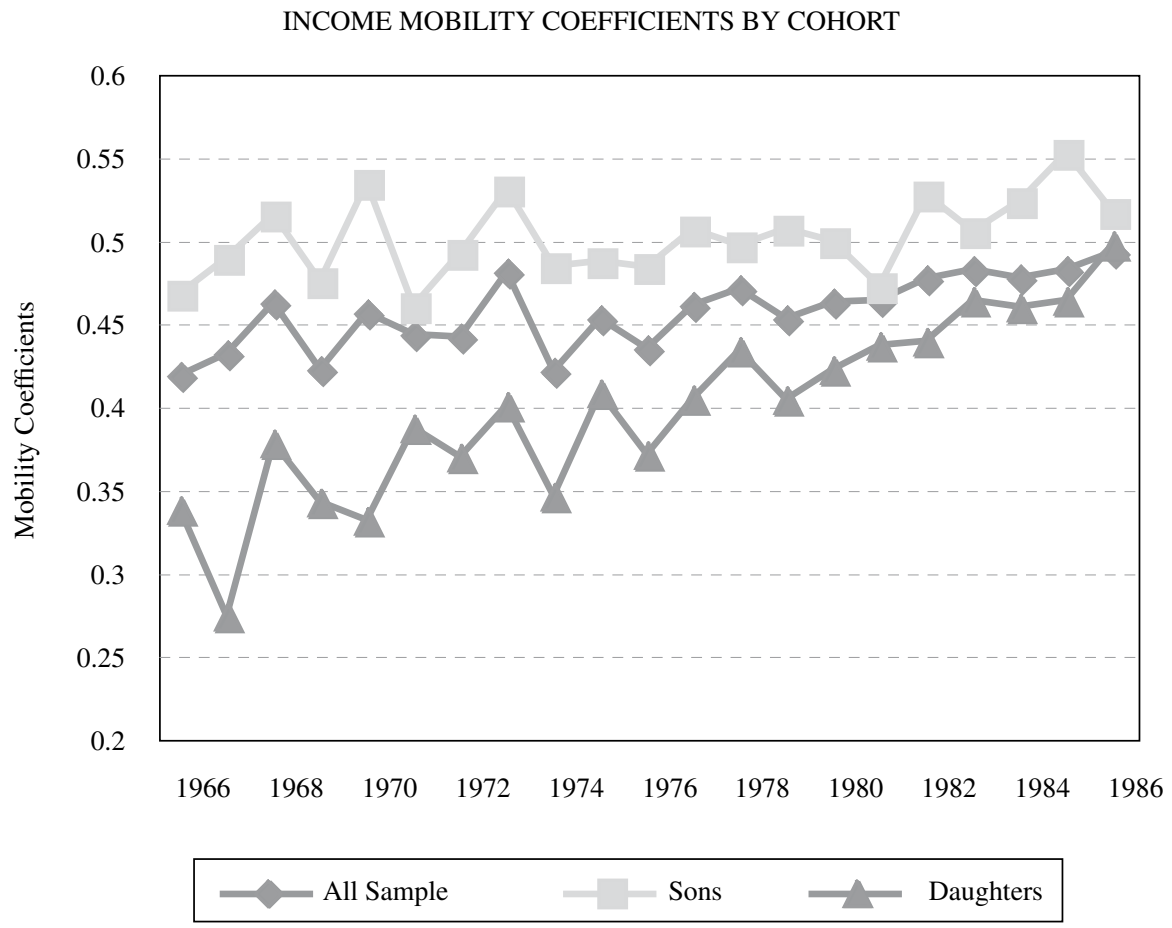

bias, by adding age and age square of both child and father in the regression. The figure shows the results for the whole sample, sons and daughters. On average, intergenerational mobility has remained the same over time. The figure shows a slight increase of the coefficient, i.e. a slight decrease of income mobility. However, sample sizes are small within each cohort with each coefficient showing similar confidence intervals. Nonetheless, as the figure shows, differences between men and women seem to matter, specially for older cohorts with a gender gap decreasing with time. This is mainly due to the fact that women has become less mobile in terms of income relative to men who have experience practically no changes in mobility with time.

Table 8 shows the income elasticity estimates using the average income of the household in two waves. Short-run income measures are " "noisy" measures for long-run or permanent income driving estimation into an attenuation inconsistency of the intergenerational of income elasticity. Solon (1992) states that the coefficient for intergenerational income correlations would be estimated with a negative bias conducting to lower measures, providing conservative results of the income elasticity, hence estimating higher mobility. As noticed before, the ideal setting would be to have average income of the household during the whole life cycle, however, this requires a larger panel data set which is not available in Chile at the moment. 


\section{TABLE 8}

OLS REGRESSIONS FOR INCOME MOBILITY: ALL SAMPLE, SONS, AND DAUGHTERS ESTIMATES. DIFFERENCES BY ANNUAL BIRTH COHORTS

\begin{tabular}{|c|c|c|c|}
\hline Variables & All Sample & Sons & Daughters \\
\hline Children log household total income in $t=1$ & $0.418 * * *$ & $0.467 * * *$ & $0.337 * * *$ \\
\hline Children age in $t=2$ & 0.180 & 0.146 & $0.342 * *$ \\
\hline - & $(0.117)$ & $(0.155)$ & $(0.139)$ \\
\hline Children age square in $t=2$ & -0.002 & -0.002 & $-0.004 * *$ \\
\hline Household head age in $t=1$ & $\begin{array}{c}(0.002) \\
0.008\end{array}$ & $\begin{array}{l}(0.002) \\
-0.059\end{array}$ & $\begin{array}{l}(0.002) \\
0.074 *\end{array}$ \\
\hline & $(0.033)$ & $(0.048)$ & $(0.043)$ \\
\hline Household head age square in $t=1$ & -0.000 & 0.000 & $-0.001 *$ \\
\hline Year $2001(=1$ if $t=2$ is $2001,=0$ if 2006$)$ & $\begin{array}{l}(0.000) \\
-0.033\end{array}$ & $\begin{array}{l}(0.000) \\
-0.016\end{array}$ & $\begin{array}{c}(0.000) \\
0.270\end{array}$ \\
\hline 10 al $2001(-111 t-2102001,-0112000)$ & $(0.525)$ & $(0.553)$ & $(0.379)$ \\
\hline Cohort 2 & $\begin{array}{c}0.013 \\
(0.033)\end{array}$ & $\begin{array}{c}0.022 \\
(0.035)\end{array}$ & $\begin{array}{c}-0.064 * * * \\
(0.020)\end{array}$ \\
\hline Cohort 3 & $0.043^{*}$ & 0.048 & 0.040 \\
\hline Cohort 4 & $(0.025)$ & $\begin{array}{c}(0.030) \\
0.008\end{array}$ & $\begin{array}{c}(0.025) \\
0.004\end{array}$ \\
\hline Condort 4 & $\begin{array}{l}0.003 \\
(0.026)\end{array}$ & $\begin{array}{c}0.008 \\
(0.028)\end{array}$ & $\begin{array}{l}0.004 \\
(0.029)\end{array}$ \\
\hline Cohort 5 & 0.037 & 0.067 & -0.007 \\
\hline Cohort 6 & $\begin{array}{c}(0.046) \\
0.024\end{array}$ & $\begin{array}{l}(0.048) \\
-0.007\end{array}$ & $\begin{array}{c}(0.036) \\
0.049\end{array}$ \\
\hline & $(0.053)$ & $(0.053)$ & $(0.042)$ \\
\hline Cohort 7 & 0.023 & 0.025 & 0.031 \\
\hline & $(0.057)$ & $(0.064)$ & $(0.046)$ \\
\hline Cohort 8 & $\begin{array}{c}0.062 \\
(0.077)\end{array}$ & $\begin{array}{c}0.063 \\
(0.084)\end{array}$ & $\begin{array}{c}0.063 \\
(0.048)\end{array}$ \\
\hline Cohort 9 & 0.002 & 0.016 & 0.008 \\
\hline Cohort 10 & 0.034 & $\begin{array}{c}(0.082) \\
0.020\end{array}$ & $\begin{array}{c}(0.053) \\
0.070\end{array}$ \\
\hline & $(0.084)$ & $(0.091)$ & $(0.062)$ \\
\hline Cohort 11 & 0.016 & 0.016 & 0.033 \\
\hline & $(0.088)$ & $(0.095)$ & $(0.066)$ \\
\hline Cohort 12 & $\begin{array}{c}0.042 \\
0.096\end{array}$ & $\begin{array}{c}0.039 \\
(0.107)\end{array}$ & $\begin{array}{c}0.067 \\
(0.068)\end{array}$ \\
\hline Cohort 13 & 0.052 & 0.029 & 0.095 \\
\hline & $(0.104)$ & $(0.114)$ & $(0.075)$ \\
\hline Cohort 14 & $\begin{array}{c}0.034 \\
(0.117)\end{array}$ & $\begin{array}{c}0.039 \\
(0.129)\end{array}$ & $\begin{array}{c}0.066 \\
(0.083)\end{array}$ \\
\hline Cohort 15 & 0.044 & 0.032 & 0.084 \\
\hline Cohort 16 & 0.045 & 0.005 & $\begin{array}{c}(0.003) \\
0.099\end{array}$ \\
\hline & $(0.131)$ & $(0.140)$ & $(0.092)$ \\
\hline Cohort 17 & 0.058 & 0.060 & 0.101 \\
\hline Cohort 18 & $\begin{array}{c}(0.137) \\
0.063\end{array}$ & $\begin{array}{c}(0.148) \\
0.038\end{array}$ & $\begin{array}{c}(0.097) \\
0.126\end{array}$ \\
\hline & $(0.145)$ & $(0.161)$ & $(0.102)$ \\
\hline Cohort 19 & 0.058 & 0.056 & 0.122 \\
\hline & $(0.155)$ & $(0.172)$ & $(0.112)$ \\
\hline Cohort 20 & 0.064 & 0.085 & 0.126 \\
\hline Cohort 21 & $\begin{array}{c}(0.163) \\
0.074\end{array}$ & $\begin{array}{c}(0.182) \\
0.049\end{array}$ & $\begin{array}{c}(0.119) \\
0.159\end{array}$ \\
\hline & $(0.170)$ & $(0.190)$ & $(0.124)$ \\
\hline Constant & 3.638 & $5.373^{*}$ & -0.431 \\
\hline & $(2.854)$ & $(3.195)$ & $(3.080)$ \\
\hline Observations & 1,539 & 668 & 867 \\
\hline R-squared & 0.336 & 0.428 & 0.339 \\
\hline Intcoho $\mathrm{F}$ test: & 2.177 & 1.798 & 3.295 \\
\hline Prob > F: & 0.00382 & 0.0267 & $1.69 \mathrm{e}-05$ \\
\hline
\end{tabular}

Standard errors in parentheses.

$* * * \mathrm{p}<0.01, * * \mathrm{p}<0.05, * \mathrm{p}<0.1$. 
The sample in this regression is composed by children who became household heads or spouse in wave 2006 and were sons or daughters in preceding waves. The average income of the household in 1996 and 2001 is a proxy for parental permanent income. This measure reduces the effect of random shocks to income measures when measured in one period and present a more smooth measure of real by reducing the bias caused by measurement error. When we estimate intergenerational mobility using parental permanent income, we obtain lower mobility than models estimated before. The intergenerational income elasticity using permanent income is $63.8 \%$, close to 14 percentage points higher than the elasticity estimates using income for one period. This suggests that using one period of income underestimates the parameter of mobility as discussed by Lee and Solon (2009).

Next, the same regressions are estimated using years of schooling. Table 9 estimates the first specifications where years of schooling of the child in adulthood are explained by years of schooling of the child's household head in childhood, childs age when his or her years of schooling are observed, this age squared, household head age when his or her years of schooling are observed, this age square, and a dummy for year of observation. The results show a correlation between years of schooling of 0.441 for the whole sample, i.e. an increase in one year of schooling of the household head in childhood increases schooling by 0.441 the years of schooling in adulthood for an average child in the sample. Gender differences are also noticeable when studying schooling mobility, since the intergenerational correlation is 0.499 for men and 0.349 for women, showing again higher mobility for the subsample of daughters than those of men.

\section{TABLE 9}

OLS REGRESSIONS FOR SCHOOLING MOBILITY: ALL SAMPLE, SONS, AND DAUGHTERS ESTIMATES

\begin{tabular}{|c|c|c|c|}
\hline Variables & All Sample & Sons & Daughters \\
\hline Household schooling in $t=1$ & $0.441 * * *$ & $\begin{array}{c}0.499 * * * \\
(0.041)\end{array}$ & $0.349 * * *$ \\
\hline Children age in $t=2$ & $\begin{array}{c}(0.033) \\
0.909 * * *\end{array}$ & $\begin{array}{l}(0.041) \\
0.944 * * *\end{array}$ & $\begin{array}{c}(0.042) \\
0.978 * * *\end{array}$ \\
\hline & $(0.205)$ & $(0.343)$ & $(0.273)$ \\
\hline Children age square in $t=2$ & $\begin{array}{l}-0.014 * * * \\
(0.004)\end{array}$ & $\begin{array}{c}-0.014 * * \\
(0.006)\end{array}$ & $\begin{array}{l}-0.015 * * * \\
(0.005)\end{array}$ \\
\hline Household head age in $t=1$ & $\begin{array}{c}0.290^{* * *} \\
(0.087)\end{array}$ & $\begin{array}{c}0.357 * * \\
(0.142)\end{array}$ & $\begin{array}{l}0.234 * * \\
(0.095)\end{array}$ \\
\hline Household head age square in $t=1$ & $\begin{array}{l}-0.002^{* * * *} \\
(0.001)\end{array}$ & $\begin{array}{c}-0.003^{* *} \\
(0.001)\end{array}$ & $\begin{array}{c}-0.002 * * \\
(0.001)\end{array}$ \\
\hline Year $2001(=1$ if $t=2$ is $2001,=0$ if 2006) & $\begin{array}{c}0.236 \\
(0.181)\end{array}$ & $\begin{array}{c}0.281 \\
(0.314)\end{array}$ & $\begin{array}{c}0.305 \\
(0.216)\end{array}$ \\
\hline Constant & $\begin{array}{c}-13.567 * * * \\
(2.831)\end{array}$ & $\begin{array}{c}-16.877 * * * \\
(4.923)\end{array}$ & $\begin{array}{c}-11.954 * * * \\
(4.134)\end{array}$ \\
\hline $\begin{array}{l}\text { Observations } \\
\text { R-squared }\end{array}$ & $\begin{array}{l}1,420 \\
0.419\end{array}$ & $\begin{array}{c}611 \\
0.491\end{array}$ & $\begin{array}{c}806 \\
0.340\end{array}$ \\
\hline
\end{tabular}

Standard errors in parentheses.

$* * * \mathrm{p}<0.01, * * \mathrm{p}<0.05, * \mathrm{p}<0.1$. 
When the correlations are interacted with aggregated cohorts (see Table 10), the results show that there are no significant effects between different cohorts. Educational mobility as well as income mobility shows no variation in the last decades. When the educational correlation coefficient interacts with annual cohorts, Figure 1 shows that there has been a slight increase in mobility, with a decreasing correlation of schooling between generations. As mentioned in the descriptive approach using mobility matrices, higher educational mobility, relative to income mobility, may be due to the increase in coverage of primary and secondary education and educational policies promoting completeness of schooling. In 2003, Chile promotes compulsory schooling for the duration of high school.

\section{TABLE 10}

OLS REGRESSIONS FOR SCHOOLING MOBILITY: ALL SAMPLE, SONS, AND DAUGHTERS ESTIMATES. DIFFERENCES BY BIRTH COHORTS

\begin{tabular}{|l|c|c|c|}
\hline \multicolumn{1}{|c|}{ Variables } & All Sample & Sons & Daughters \\
\hline Household schooling in $t=1$ & $0.477^{* * *}$ & $0.516^{* * *}$ & $0.392^{* * * *}$ \\
Children age in $t=2$ & $(0.062)$ & $(0.097)$ & $(0.096)$ \\
Children age square in $t=2$ & $0.716^{* * *}$ & 0.598 & $0.983^{* * *}$ \\
& $(0.212)$ & $(0.363)$ & $(0.288)$ \\
Household head age in $t=1$ & $-0.011^{* * *}$ & -0.009 & $-0.015^{* * *}$ \\
& $(0.004)$ & $(0.006)$ & $(0.005)$ \\
Household head age square in $t=1$ & $0.279^{* * *}$ & $0.327 *$ & $0.211^{* *}$ \\
& $(0.092)$ & $(0.166)$ & $(0.094)$ \\
Year 2001 (= 1 if $t=2$ is $2001,=0$ if 2006) & $-0.002^{* *}$ & $-0.003^{*}$ & $-0.002^{*}$ \\
& $(0.001)$ & $(0.002)$ & $(0.001)$ \\
Household head schooling in $t=1 *$ Cohort (1970-1979) $)$ & -0.037 & -0.086 & 0.212 \\
& $(0.252)$ & $(0.467)$ & $(0.266)$ \\
Household head schooling in $t=1 *$ Cohort (1980-1989) & -0.013 & 0.015 & -0.040 \\
& -0.096 & $(0.120)$ & $(0.087)$ \\
Constant & $(0.076)$ & -0.132 & -0.060 \\
& $-9.812^{* * *}$ & $-10.133)$ & $(0.096)$ \\
& $(3.488)$ & $(6.478)$ & $-11.170 * *$ \\
Observations & 1,406 & $6.588)$ \\
R-squared & 0.423 & 0.505 & 798 \\
\hline
\end{tabular}

Standard errors in parentheses.

$* * * \mathrm{p}<0.01, * * \mathrm{p}<0.05, * \mathrm{p}<0.1$.

An important issue with the measures presented above is that mobility measurements depend on the initial position of individuals in the distribution of income or schooling or measures of relative mobility. To account for this positional movement the variables of interest are transformed to percentiles of income and deciles of schooling. In this sense, new estimates will show the intergenerational correlation between positions in the distribution across time. The regressions that estimate the correlation coefficient are the simplest regression used in previous results shown in Table 5 and Table 9.

Tables 12 and 13 show the intergenerational correlation coefficient for income percentiles and schooling deciles. The coefficient using the whole sample shows that 
TABLE 11

OLS REGRESSIONS FOR SCHOOLING MOBILITY: ALL SAMPLE, SONS, AND DAUGHTERS ESTIMATES. DIFFERENCES BY ANNUAL BIRTH COHORTS

\begin{tabular}{|c|c|c|c|}
\hline Variables & All Sample & Sons & Daughters \\
\hline Household schooling in $t=1$ & $\begin{array}{l}0.334 * \\
(0.200)\end{array}$ & $\begin{array}{c}0.427 * * \\
(0.205)\end{array}$ & $\begin{array}{c}0.282 \\
(0.372)\end{array}$ \\
\hline Children age in $t=2$ & 0.346 & 0.422 & $0.540 * *$ \\
\hline & $(0.220)$ & $(0.335)$ & $(0.240)$ \\
\hline Children age square in $t=2$ & $\begin{array}{l}-0.006 \\
(0.004)\end{array}$ & $\begin{array}{l}-0.008 \\
(0.006)\end{array}$ & $\begin{array}{l}-0.007 \\
(0.005)\end{array}$ \\
\hline Household head age in $t=1$ & $\begin{array}{c}0.339 * * \\
(0.133)\end{array}$ & $\begin{array}{c}0.656 * * * \\
(0.231)\end{array}$ & $\begin{array}{c}0.188^{* * *} \\
(0.095)\end{array}$ \\
\hline Household head age square in $t=1$ & $-0.003 * *$ & $-0.006^{* * *}$ & -0.001 \\
\hline Year $2001(=1$ if $t=2$ is $2001,=0$ if 2006) & $\begin{array}{l}(0.001) \\
-0.318\end{array}$ & $\begin{array}{l}(0.002) \\
-0.559\end{array}$ & $\begin{array}{c}(0.001) \\
0.299\end{array}$ \\
\hline & $(0.332)$ & $(0.562)$ & $(0.421)$ \\
\hline Cohort 2 & $\begin{array}{l}0.052 \\
(0.209)\end{array}$ & $\begin{array}{c}0.064 \\
(0.206)\end{array}$ & $\begin{array}{c}0.067 \\
(0.281)\end{array}$ \\
\hline Cohort 3 & 0.135 & $\begin{array}{l}-0.051 \\
(0.190)\end{array}$ & $\begin{array}{c}0.092 \\
(0.292)\end{array}$ \\
\hline Cohort 4 & $\begin{array}{c}0.211 \\
(0.235)\end{array}$ & $\begin{array}{c}0.277 \\
(0.275)\end{array}$ & $\begin{array}{c}0.023 \\
(0.362)\end{array}$ \\
\hline Cohort 5 & $\begin{array}{l}0.356^{*} \\
(0.195)\end{array}$ & $\begin{array}{l}0.370^{*} \\
(0.189)\end{array}$ & $\begin{array}{c}0.201 \\
(0.306)\end{array}$ \\
\hline Cohort 6 & $\begin{array}{c}0.079 \\
(0.195)\end{array}$ & $\begin{array}{l}-0.135 \\
(0.253)\end{array}$ & $\begin{array}{c}0.051 \\
(0.310)\end{array}$ \\
\hline Cohort 7 & $\begin{array}{c}0.129 \\
(0.214)\end{array}$ & $\begin{array}{c}0.056 \\
(0.221)\end{array}$ & $\begin{array}{c}0.040 \\
(0.305)\end{array}$ \\
\hline Cohort 8 & $\begin{array}{l}0.156 \\
(0.197)\end{array}$ & $\begin{array}{c}0.096 \\
(0.197)\end{array}$ & $\begin{array}{c}0.071 \\
(0.322)\end{array}$ \\
\hline Cohort 9 & $\begin{array}{l}-0.041 \\
(0.217)\end{array}$ & $\begin{array}{l}-0.171 \\
(0.213)\end{array}$ & $\begin{array}{l}-0.028 \\
(0.373)\end{array}$ \\
\hline Cohort 10 & $\begin{array}{c}0.185 \\
(0.201)\end{array}$ & $\begin{array}{c}0.109 \\
(0.205)\end{array}$ & $\begin{array}{c}0.151 \\
(0.342)\end{array}$ \\
\hline Cohort 11 & $\begin{array}{c}0.075 \\
(0.206)\end{array}$ & $\begin{array}{c}0.027 \\
(0.224)\end{array}$ & $\begin{array}{c}0.021 \\
(0.356)\end{array}$ \\
\hline Cohort 12 & $\begin{array}{c}0.077 \\
(0.209)\end{array}$ & $\begin{array}{l}-0.097 \\
(0.241)\end{array}$ & $\begin{array}{c}0.161 \\
(0.350)\end{array}$ \\
\hline Cohort 13 & $\begin{array}{c}0.023 \\
(0.202)\end{array}$ & $\begin{array}{l}-0.147 \\
(0.213)\end{array}$ & $\begin{array}{c}0.073 \\
(0.352)\end{array}$ \\
\hline Cohort 14 & $\begin{array}{l}-0.038 \\
(0.203)\end{array}$ & $\begin{array}{l}-0.127 \\
(0.257)\end{array}$ & $\begin{array}{l}-0.037 \\
(0.362)\end{array}$ \\
\hline Cohort 15 & -0.031 & -0.195 & $\begin{array}{c}0.022 \\
(0.368)\end{array}$ \\
\hline Cohort 16 & -0.026 & -0.161 & 0.013 \\
\hline & $(0.204)$ & $(0.223)$ & $(0.374)$ \\
\hline Cohort 17 & $\begin{array}{c}0.004 \\
(0.207)\end{array}$ & $\begin{array}{l}-0.098 \\
(0.222)\end{array}$ & $\begin{array}{c}0.070 \\
(0.387)\end{array}$ \\
\hline Cohort 18 & -0.008 & -0.110 & 0.040 \\
\hline Cohort 19 & -0.011 & $\begin{array}{l}(0.246) \\
-0.142\end{array}$ & $\begin{array}{c}(0.390) \\
0.051\end{array}$ \\
\hline & $(0.210)$ & $(0.252)$ & $(0.395)$ \\
\hline Cohort 20 & $\begin{array}{l}-0.041 \\
(0.209)\end{array}$ & $\begin{array}{l}-0.199 \\
(0.287)\end{array}$ & $\begin{array}{c}0.043 \\
(0.397)\end{array}$ \\
\hline Cohort 21 & -0.074 & -0.356 & 0.039 \\
\hline & $(0.215)$ & $(0.241)$ & $(0.405)$ \\
\hline Constant & $\begin{array}{l}-4.796 \\
(4.374)\end{array}$ & $\begin{array}{c}-13.355^{*} \\
(7.167)\end{array}$ & $\begin{array}{l}-4.604 \\
(4.177)\end{array}$ \\
\hline Observations & 1,374 & 592 & 779 \\
\hline R-squared & 0.461 & 0.573 & 0.375 \\
\hline Intcoho $\mathrm{F}$ test: & 3.394 & 5.162 & 1.348 \\
\hline Prob > F: & $6.71 \mathrm{e}-06$ & $3.80 \mathrm{e}-09$ & 0.159 \\
\hline
\end{tabular}

Standard errors in parentheses.

$* * * \mathrm{p}<0.01, * * \mathrm{p}<0.05, * \mathrm{p}<0.1$. 


\section{TABLE 12}

OLS REGRESSIONS FOR RELATIVE INCOME MOBILITY: ALL SAMPLE, SONS, AND DAUGHTERS ESTIMATES

\begin{tabular}{|l|c|c|c|}
\hline \multicolumn{1}{|c|}{ Variables } & All Sample & Sons & Daughters \\
\hline Household income percentile in $t=1$ & $0.519^{* * *}$ & $0.597 * * *$ & $0.444^{* * *}$ \\
Children age in $t=2$ & $(0.048)$ & $(0.069)$ & $(0.052)$ \\
& $5.908 * * *$ & $6.774 * *$ & $5.789^{* *}$ \\
Children age square in $t=2$ & $(2.185)$ & $(2.968)$ & $(2.778)$ \\
& $-0.097 * * *$ & $-0.104 * *$ & $-0.095^{* *}$ \\
Household head age in $t=1$ & $(0.037)$ & $(0.046)$ & $(0.048)$ \\
& -0.832 & $-2.784 * *$ & 1.238 \\
Household head age square in $t=1$ & $(0.894)$ & $(1.314)$ & $(1.380)$ \\
& 0.008 & $0.023^{* *}$ & -0.010 \\
Year 2001 (= 1 if $t=2$ is 2001, $=0$ if 2006) & $(0.008)$ & $(0.011)$ & $(0.014)$ \\
Constant & $-7.457 * * *$ & $-5.319 *$ & $-8.342^{* *}$ \\
& $(2.803)$ & $(3.093)$ & $(3.506)$ \\
Observations & -34.382 & -2.862 & -81.661 \\
R-squared & $(35.343)$ & $(39.831)$ & $(50.649)$ \\
\hline
\end{tabular}

Standard errors in parentheses.

$* * * \mathrm{p}<0.01, * * \mathrm{p}<0.05, * \mathrm{p}<0.1$.

\section{TABLE 13}

OLS REGRESSIONS FOR RELATIVE SCHOOLING MOBILITY: ALL SAMPLE, SONS, AND DAUGHTERS ESTIMATES

\begin{tabular}{|l|c|c|c|}
\hline \multicolumn{1}{|c|}{ Variables } & All Sample & Sons & Daughters \\
\hline Household head schooling decile in $t=1$ & $0.613^{* * *}$ & $0.642^{* * *}$ & $0.571^{* * *}$ \\
& $(0.061)$ & $(0.095)$ & $(0.074)$ \\
Children age in $t=2$ & $1.321^{* * *}$ & $1.258^{* * *}$ & $1.361^{* * *}$ \\
& $(0.283)$ & $(0.373)$ & $(0.356)$ \\
Children age square in $t=2$ & $-0.019^{* * *}$ & $-0.018^{* * *}$ & $-0.020^{* * *}$ \\
& $(0.005)$ & $(0.006)$ & $(0.006)$ \\
Household head age in $t=1$ & 0.171 & 0.076 & 0.245 \\
& $(0.109)$ & $(0.153)$ & $(0.178)$ \\
Household head age square in $t=1$ & -0.001 & -0.001 & -0.002 \\
& $(0.001)$ & $(0.001)$ & $(0.002)$ \\
Year 2001 (=1 if $t=2$ is 2001, $=0$ if 2006) & $0.471^{*}$ & $0.873^{* *}$ & 0.189 \\
Constant & $(0.263)$ & $(0.437)$ & $(0.333)$ \\
& $-25.554 * * *$ & $-22.557^{* * *}$ & $-27.721 * * *$ \\
Observations & $(3.902)$ & $(5.820)$ & $(5.219)$ \\
R-squared & 1,420 & 611 & 806 \\
\end{tabular}

Standard errors in parentheses.

*** $\mathrm{p}<0.01,{ }^{* *} \mathrm{p}<0.05, * \mathrm{p}<0.1$. 


\section{FIGURE 3}

\section{SCHOOLING MOBILITY COEFFICIENTS BY COHORT}

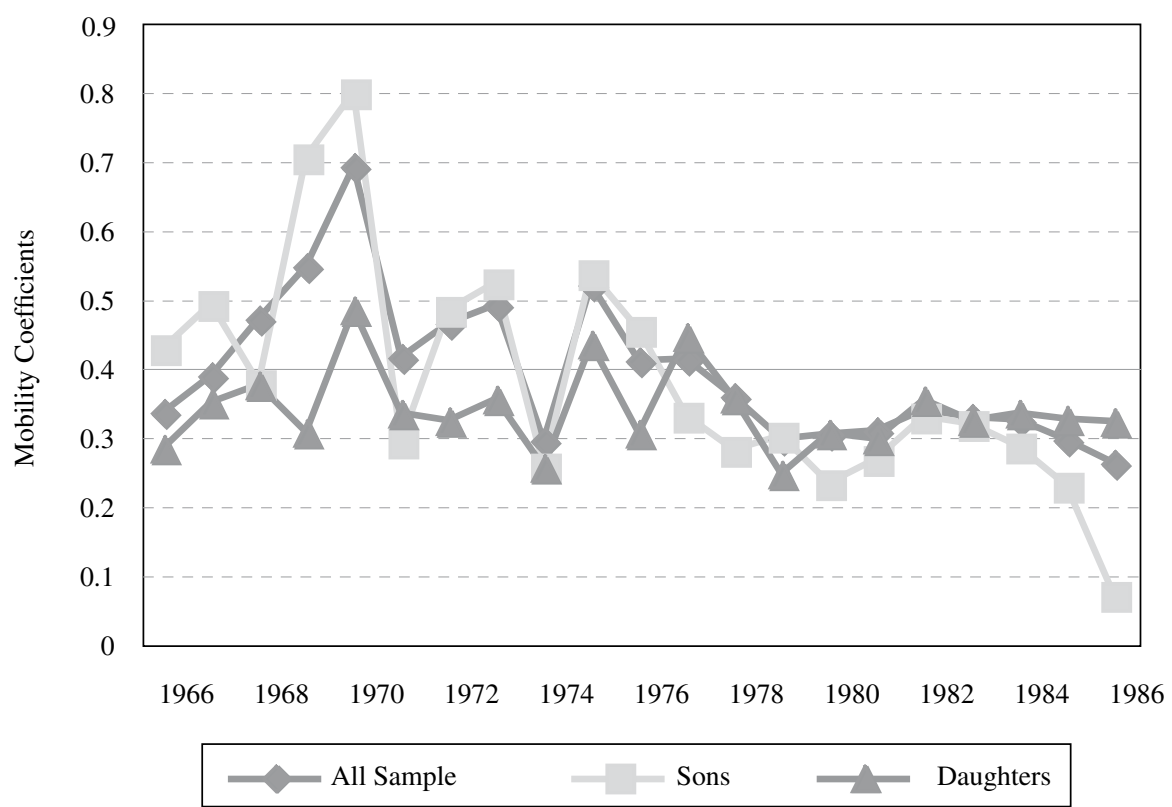

the percentile correlation between periods is 0.519 . This shows that an additional percentile in the percentile income distribution as a child increases the position in the percentile income distribution by 0.519 percentile in adulthood. This result is higher for the subsample of men. The correlation is 0.597 for men and 0.444 for the subsample of women. Absolute and relative measures of income mobility show higher mobility for women. The correlation coefficient for relative schooling mobility using the whole sample is 0.613 . An additional decile of schooling in the initial distribution increases the decile position in adulthood by 0.613 deciles. This result is lower for the subsample of women, showing again higher mobility for women. Even though straight comparisons between the measures of absolute and relative mobility are complex, both measures show low intergenerational mobility and higher mobility for women.

\section{CONCLUSIONS}

Previous analyses of the transmission of economic status in Chile have used cross-sectional data to estimate the intergenerational income elasticity, and have not observed longitudinal data. For instance, Núñez and Risco (2004) and Torche (2005) 
use a separate data set on the parent's generation to estimate a first-stage regression of parent's log incomes on their education and occupation. After that, in a second stage, they estimate the regression of the children's log incomes on a prediction of his or her parent's log incomes based on the first-stage regression. As Solon (2002) highlights, the two-stage procedure that uses education and occupation to predict parent's incomes is likely to lead to an upward bias resulting in less social mobility than there is in reality. The problem is that these first-stage parent's variables are not only associated with the children's incomes, but also might be positive predictors of the children's income even after conditioning on the parent's incomes. In the secondstage regression, when the parent's education and occupation is used only to predict the parent's incomes, but not as a separate explanatory variable in its own right, the resulting omitted-variables bias may lead to overestimation of the intergenerational earnings elasticity. In this way, their estimate may be biased upward by their prediction of parent's income on the basis of their education and occupation.

In this paper we overcome this problem by relying on observed data for both parents and children. We analyze intergenerational income mobility during the 1996-2006 decade in Chile by using the most extended household panel survey of the country. Following the recent literature, we control our estimates for time-series variation (Lee and Solon (2009), Mayer and Lopoo (2004)). We also present two set of estimates: one with parents' household incomes measured in the first wave only, and another with parents' household incomes measured across the first two waves. In this sense, our results from the first set will provide conservative estimates of the degree of intergenerational transmission of income. And the second set of estimates will produce an approximation to use a measure of permanent income rather than current income.

Our results show high intergenerational income elasticities in comparison to other developing countries, and these values are higher for sons than for daughters. However, the estimates are lower than those estimated by the previous literature showing that the two stage procedure produces an overestimation of the intergenerational income elasticities. When analyzing cohorts, the results suggest that there are not significant changes in the measures of income mobility. The results also show that schooling mobility is higher than income mobility, however not for high levels of schooling. That may be due to the increase in primary and secondary education coverage during the last 50 years, showing that schooling policies seem to be effective in coverage but not in promoting education as a source of higher mobility. When relative measures of mobility are estimated the results show low levels of relative mobility for income percentiles and schooling deciles. These results also show that women are more mobile than men.

\section{REFERENCES}

BJORKLUD, A. and M. JANTTI (1997). "Intergenerational income mobility in Sweden compared to the United States", The American Economic Review 87 (5), pp. 1009-1018.

CONTRERAS, D. (1999). "Distribución del ingreso en Chile: Nueve hechos y algunos mitos", Revista Perspectivas 1 (2), pp. 311-332. 
FIELDS, G. S., R. DUVAL, S. FREIJE, and M. L. SANCHEZ (2006). Income mobility in Latin America. Center for International Development, Harvard University.

FRANCESCONI, M. and C. NICOLETTI (2006). "Intergenerational mobility and sample selection in short panels", Journal of Applied Econometrics 21 (8), pp. 1265-1293.

GALIANI, S. (2010). "Social mobility: What is it and why does it matter?", Documento de Trabajo 101, Centro de Estudios Distributivos, Laborales y Sociales. Universidad Nacional de La Plata.

JENKINS, S. P. and T. SIEDLER (2007b). "Using household panel data to understand the inter-generational transmission of poverty", Working Papers of Chronic Poverty Research Centre 74.

LAWSON, D., A. MCKAY, and K. MOORE (2003). Panel datasets in developing and transitional countries. Available at http://www.chronicpoverty.org

LEE, C.-I. and G. SOLON (2009). "Trends in intergenerational income mobility", Review of Economics and Statistics 91(4), pp. 766-772.

LOPEZ, R. and S. J. MILLER (2008, December). "Chile: The unbearable burden of inequality", World Development 36 (12), pp. 2679-2695.

MAYER, S. E. and L. M. LOPOO (2004). What do trends in the intergenerational economic mobility of sons and daughters in the United States mean? Generational Income Mobility in North America and Europe, edited by Miles Corak. Cambridge University Press.

MAYER, S. E. and L. M. LOPOO (2008). "Government spending and intergenerational mobility”, Journal of Public Economics 92 (1-2), pp. 139-158.

MELLER, P. (2000). Pobreza y distribución del ingreso en Chile (década del 90), Serie de Economía 69, Ingeniería Industrial, Universidad de Chile.

NUÑEZ, J. and C. RISCO (2004, December). "Intergenerational income mobility in a developing country: The case of Chile", Documento de Trabajo 210, Departamento de Economía, Universidad de Chile.

PAREDES, R. D.; J. J. PRIETO, and J. R. ZUBIZARRETA (2006). "Intergenerational mobility and sample selection in short panels", Documento de Trabajo, pp. 1265-1293.

SAPELLI, C. (2005). "Returns to schooling and income distribution by cohort in Chile: An analysis based in synthetic panel data", Documento de Trabajo número 290, Instituto de Economía, Universidad Católica de Chile.

SHORROCKS, A. (1978). "The measurement of mobility", Econometrica 46 (5), pp. 1013-1024.

SOLIMANO, A. and A. TORCHE (2008). "La distribución del ingreso en Chile 1987-2003: Análisis y consideraciones de política", Documento de Trabajo 480, Banco Central de Chile.

SOLON, G. (1992). "Intergenerational income mobility in the United States", The American Economic Review 82 (3), pp. 393-408.

SOLON, G. (2002). "Cross-country differences in intergenerational earnings mobility", Journal of Economic Perspectives 16 (3), pp. 59-66.

TORCHE, F. (2005). "Unequal but fluid: Social mobility in Chile in comparative perspective", American Sociological Review 70 (3), pp. 422-450.

ZUBIZARRETA, J. R. (2009). "Educational outcomes of the children of the poor: the Chilean case". Background paper prepared for the Human Development Report 2008/2009 for Latin America and the Caribbean, United Nations Development Plan. 
